\title{
Flavonoids from Artemisia sacrorum Ledeb. and their cytotoxic activities against human cancer cell lines
}

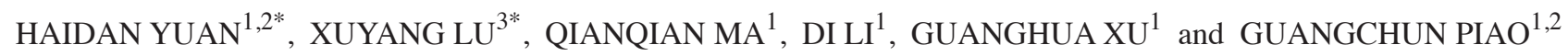 \\ ${ }^{1}$ Department of Pharmacognosy, College of Pharmacy; ${ }^{2}$ Key Laboratory of Natural Resources of Changbai Mountain and \\ Functional Molecules, Ministry of Education, Yanbian University, Yanji, Jilin 133000; \\ ${ }^{3}$ Department of Pharmacy, Jilin Central Hospital, Jilin, Jilin 132000, P.R. China
}

Received March 10, 2015; Accepted June 1, 2016

DOI: $10.3892 / \mathrm{etm} .2016 .3556$

\begin{abstract}
Flavonoids have been demonstrated to have cytotoxic activities toward numerous human cancer cells, whereas they have little or no effect on normal cells. The numerous flavonoids in traditional Chinese herbs may be promising candidates for the development of novel anti-cancer drugs. Our previous study demonstrated that $\mathrm{CH}_{2} \mathrm{Cl}_{2}$ and $95 \%$ ethanol eluate (EE) fractions have the strongest cytotoxic activities against human cancer cell lines of the 9 fractions separated from Artemisia sacrorum Ledeb., which is widely used to prevent and treat diverse diseases in Northeast China. In the present study, 8 flavonoids were isolated from the $95 \% \mathrm{EE}$ fraction of Artemisia sacrorum Ledeb. The chemical structures of the compounds were elucidated by extensive spectroscopic analyses. The following 5 flavonoids were isolated for the first time from this plant: Jaceosidin, kaempferol, quercetin, luteolin and quercitrin. A total of 2 flavonoids from the $\mathrm{CH}_{2} \mathrm{Cl}_{2}$ fraction and 8 flavonoids from the $95 \%$ EE fraction were examined to evaluate their cytotoxic activities against human SK-HEP-1 hepatoma cancer cells and human HeLa cervical cancer cells, respectively. The results revealed that 2 flavonoids had marked cytotoxic activities against HeLa cells.
\end{abstract}

\section{Introduction}

The majority of approved anticancer drugs are either natural products or have been developed based on knowledge gained from natural products, which have been important in the search for novel anticancer drugs compared with other areas of drug development (1-5). Traditional Chinese medicine has

Correspondence to: Dr Guangchun Piao, Department of Pharmacognosy, College of Pharmacy, Yanbian University, 977 Gongyuan Road, Yanji, Jilin 133000, P.R. China

E-mail: gcpiao@ybu.edu.cn

${ }^{*}$ Contributed equally

Key words: Artemisia sacrorum Ledeb., flavonoids, cytotoxic activities, human cancer cell lines been historically used to treat disease using natural products. Although certain traditional Chinese herbs should no longer be used, other traditional Chinese herbs that have been proven to be effective have been gradually incorporated into modern medicine (6).

Among these traditional Chinese medicinal plants, Artemisia sacrorum Ledeb (ASL; Compositae) is of particular interest as it is widely used to prevent and treat diverse diseases in the Yanbian area of Northeast China $(7,8)$. Previous studies have indicated that the water-soluble parts of the A. sacrorum extract were protective against carbon tetrachloride and acetaminophen-induced hepatotoxicity in mice, and the underlying mechanisms have been investigated (9-11). In a previous study, A. sacrorum was demonstrated to prevent $\mathrm{N}$-acetyl-p-aminophenol (APAP)-induced apoptosis and necrosis, as indicated by liver histopathological and immunohistochemical analysis, and DNA laddering (9-11). According to the results from a western blot analysis, the ethanol eluate precipitation (EEP) decreased APAP-induced caspase- 3 and -8 protein expression levels in mouse livers (9-11). Furthermore, ASL was able to inhibit adipocyte differentiation and adipogenesis through the activation of 5'-adenosine monophosphate-activated protein kinase (AMPK) in 3T3-L1 adipocytes and hepatocellular carcinoma (HepG2) cells, respectively $(12,13)$. Petroleum ether fraction of $A$. sacrorum Ledeb, another extract from A. sacrorum, inhibited glucose production via the AMPK-glycogen synthase kinase-cAMP response element binding protein signaling pathway in HepG2 cells (14). Notably, the cytotoxicities of the 9 fractions separated from A. sacrorum via the two extraction methods was investigated in our previous study, and the results demonstrated that the $\mathrm{CH}_{2} \mathrm{Cl}_{2}$ and $95 \%$ ethanol eluate (EE) fractions revealed the strongest cytotoxic activities against 3 human cancer cell lines. In addition, a subsequent study demonstrated that 10 compounds, of which 2 were flavonoids, were isolated from the $\mathrm{CH}_{2} \mathrm{Cl}_{2}$ fraction (15).

The present study aimed to investigate the isolation and structure of the compounds from the $95 \%$ EE fraction of A. sacrorum. The results demonstrated that this fraction was markedly rich in flavonoids. Flavonoids are cancer-preventive agents, and have been shown to be particularly important (16-18). Therefore, the present study was further conducted to evaluate the cytotoxic activities of all flavonoids from the $\mathrm{CH}_{2} \mathrm{Cl}_{2}$ and 95\% EE fractions. 


\section{Materials and methods}

General experimental procedures. The nuclear magnetic resonance (NMR) spectra of compounds 1, 2, 3, 5, 6, and 7 were recorded on a Bruker $500 \mathrm{MHz}$ NMR spectrometer (Bruker Corporation, Billerica, MA, USA), operating at a frequency of $500 \mathrm{MHz}$ for ${ }^{1} \mathrm{H}$ and $125 \mathrm{MHz}$ for ${ }^{13} \mathrm{C}$ nuclei at room temperature, and with TMS as the internal standard. The NMR spectra of compounds 4 and 8 were recorded on a Bruker $300 \mathrm{MHz}$ NMR spectrometer, operating at $300 \mathrm{MHz}$ for ${ }^{1} \mathrm{H}$ and $75 \mathrm{MHz}$ for ${ }^{13} \mathrm{C}$ nuclei at room temperature with tetramethylsilane (TMS) as the internal standard. Chemical shifts ( $\delta$ ) were expressed in parts per million (ppm) relative to TMS. The chemical shifts

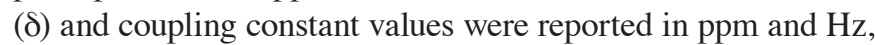
respectively. Compounds 1, 2, 3, 4, 6, and 7 were dissolved in $\mathrm{CD}_{3} \mathrm{OD}, 5$ was dissolved in dimethyl sulfoxide (DMSO), and 8 was dissolved in acetone- $\mathrm{d}_{6}$. Column chromatography (CC) was performed on a Sephadex LH-20 (18-111 $\mu$ m; GE Healthcare Biosciences, Pittsburgh, PA, USA), YMC-GEL octadecyl (ODS)-A (50 $\mu \mathrm{m}$; YMC Co., Ltd., Kyoto, Japan) and silica gel (200-300 mesh, Qingdao Marine Chemical, Ltd., Qingdao, China) columns. D-101 macroporous absorption resin was purchased from Tianjin Haiguang Chemical Co., Ltd. (Tianjin, China). Silica gel 60F254 plates (20x20 cm; $0.2 \mathrm{~mm}$ thick; Merck, Darmstadt, Germany) and silica gel GF 254 (Qingdao Marine Chemical Co., Ltd.) were used for thin-layer chromatography (TLC) analysis. The $\mathrm{CH}_{3} \mathrm{OH}$ used for column chromatography was high performance liquid chromatography-grade (Jiangsu Hanbang Science and Technology Co., Ltd., Jiangsu, China). All other chemicals and reagents used in the present study were of analytical grade.

Plant material. The aerial parts of ASL (Compositae) were collected in July 2008 from Xidong, Yanji in Jilin. The plant was taxonomically identified and authenticated by Professor Huizi Lv (College of Pharmacy, Yanbian University of China, Yanji, China). A specimen of the plant was deposited at the College of Pharmacy, Yanbian University.

Extraction and isolation. A total of $5 \mathrm{~kg}$ of the aerial parts of A. sacrorum were collected, air-dried in the shade, and dissolved in boiling water twice (Figs. 1 and 2). The extract was then separated on a D-101 macroporous absorption resin to elute water, 50\% EE and 95\% EE fractions. From this separation, the 95\% EE fraction (16.03 g) was chromatographed on a silica-gel column (200-300 mesh) with petroleum ether-EtOAc in a stepwise gradient elution (50:1-0:100). The eluates were combined based on the TLC results in order to produce 8 fractions (1-8).

The fractions were chromatographed as follows: Fraction 2 was chromatographed on an ODS column by eluting with gradient mixtures of $\mathrm{CH}_{3} \mathrm{OH}$ and $\mathrm{H}_{2} \mathrm{O}(8: 2$ to $10: 0)$ in order to obtain 7 subfractions (2.1-7). Subfraction 2.3 was rechromatographed on a Sephadex LH-20 column by eluting with gradient mixtures of $\mathrm{CH}_{3} \mathrm{OH}$ and $\mathrm{H}_{2} \mathrm{O}(8: 2$ to $10: 0)$ to obtain compound A ( $3.0 \mathrm{mg})$. Fraction 3 was rechromatographed on an ODS column by eluting with gradient mixtures of $\mathrm{CH}_{3} \mathrm{OH}$ and $\mathrm{H}_{2} \mathrm{O}$ (7:3 to 10:0) to afford compound $1(23.2 \mathrm{mg})$. Fraction 4 was rechromatographed on an ODS column by eluting with gradient mixtures of $\mathrm{CH}_{3} \mathrm{OH}$ and $\mathrm{H}_{2} \mathrm{O}$ (6:4 to 10:0) to obtain 11 subfractions (4.1-11). Subfraction 4.3 was rechromatographed on a Sephadex LH-20 column by eluting with gradient mixtures of $\mathrm{CH}_{3} \mathrm{OH}$ and $\mathrm{H}_{2} \mathrm{O}$ (8:2 to 10:0) to obtain compound 2 (2.6 mg) and compound $3(1.5 \mathrm{mg})$. Subfraction 4.6 was subjected to a Sephadex LH-20 column by eluting with gradient mixtures of $\mathrm{CH}_{3} \mathrm{OH}$ and $\mathrm{H}_{2} \mathrm{O}$ (7:3 to 10:0) to obtain compound 4 (8.2 mg). Fraction 5 was rechromatographed on a Sephadex LH-20 column by eluting with $\mathrm{CH}_{3} \mathrm{OH}-\mathrm{H}_{2} \mathrm{O}$ (7:3 to 10:0) to obtain compound 5 (2.0 mg) and 12 subfractions (5.1-12). Subfraction 5.10 was subjected to a Sephadex LH-20 column by eluting with gradient mixtures of $\mathrm{CH}_{3} \mathrm{OH}$ and $\mathrm{H}_{2} \mathrm{O}(8: 2$ to 10:0) to obtain compound 6 $(1.5 \mathrm{mg})$. Fraction 6 was rechromatographed on an ODS column by eluting with gradient mixtures of $\mathrm{CH}_{3} \mathrm{OH}$ and $\mathrm{H}_{2} \mathrm{O}$ (6:4 to 10:0) to obtain eight subfractions (6.1-8). Subfraction 6.6 was subjected to a Sephadex LH-20 column repeatedly to obtain compound 7 (2.6 mg). Fraction 7 was rechromatographed on a Sephadex LH-20 column by eluting with gradient mixtures of $\mathrm{CH}_{3} \mathrm{OH}-\mathrm{H}_{2} \mathrm{O}$ (4:6 to 10:0) to produce 5 subfractions (7.1-5). Finally, subfraction 7.2 was subjected to a Sephadex LH-20 column once more by eluting with gradient mixtures of $\mathrm{CH}_{3} \mathrm{OH}$ and $\mathrm{H}_{2} \mathrm{O}(6: 4$ to $10: 0)$ to afford compound $8(6.0 \mathrm{mg})$.

Cell culture and MTS assay. The two human cancer cell lines (SK-HEP-1 and HeLa) and one normal human cell line (HEK293) used in the cytotoxic assay were purchased from American Type Culture Collection (Manassas, VA, USA). All cell lines were cultured in Dulbecco's modified Eagle medium supplemented with $10 \%$ fetal bovine serum, 100 units $/ \mathrm{ml}$ penicillin and $100 \mathrm{mg} / \mathrm{ml}$ streptomycin and kept at $37^{\circ} \mathrm{C}$ in a humidified atmosphere containing $5 \% \mathrm{CO}_{2}$.

A 200- $\mu \mathrm{l}$ aliquot of adherent cells was used to seed 96-well cell culture plates at $3 \times 10^{4}$ cells/well and allowed to adhere for $6 \mathrm{~h}$ prior to drug addition. Each cell line was treated with 0,5, $10,25,50,100$ and $200 \mu \mathrm{M}$ of flavonoids for $48 \mathrm{~h}$. Subsequently, $20 \mu \mathrm{l}$ MTS reagent was added into each well and incubated for $1 \mathrm{~h}$. The cell viability was detected by the CellTiter 96 AQueous One solution Cell Proliferation Assay kit (Promega Corporation, Madison, WI, USA).

\section{Results and Discussion}

To observe the cytotoxic activity of the herb, A. sacrorum was extracted and isolated by $95 \% \mathrm{EtOH}$ and water, as described in our previous study (15). Following extraction with $95 \% \mathrm{EtOH}$ extract with various solvents, and separation of the water extract with a D-101 macroporous resin column, 9 fractions of A. sacrorum were obtained, of which the $95 \% \mathrm{EE}$ and $\mathrm{CH}_{2} \mathrm{Cl}_{2}$ fraction revealed the strongest cytotoxity against 3 human cancer cell lines. In a subsequent study, 2 flavonoids were isolated from the $\mathrm{CH}_{2} \mathrm{Cl}_{2}$ fraction (15). In the present study, 9 compounds were isolated from the $95 \% \mathrm{EE}$ fraction.

Compound 1 was isolated as yellow, needle-like crystals (acetone). The ${ }^{1} \mathrm{H}-\mathrm{NMR}$ and ${ }^{13} \mathrm{C}-\mathrm{NMR}$ spectra of the compound revealed the characteristic signals of a flavonoid. The ${ }^{1} \mathrm{H}-\mathrm{NMR}$ spectrum exhibited two proton signals at $\delta 6.56(1 \mathrm{H} ; \mathrm{s})$ and 6.61 $(1 \mathrm{H} ; \mathrm{s})$, which represented the proton signals of $\mathrm{C} 3-\mathrm{H}$ and $\mathrm{C} 8-\mathrm{H}$ of the A ring, respectively. Signals at $\delta 7.45(1 \mathrm{H} ; \mathrm{d} ; J=2.0 \mathrm{~Hz})$, $6.92(1 \mathrm{H} ; \mathrm{d} ; J=8.35 \mathrm{~Hz})$ and $7.49(1 \mathrm{H}$; dd; $J=2.0 ; 8.35 \mathrm{~Hz})$ represented the proton signals of $\mathrm{C}^{\prime}-\mathrm{H}, \mathrm{C} 5^{\prime}-\mathrm{H}$ and $\mathrm{C}^{\prime}-\mathrm{H}$ of the $\mathrm{B}$ ring. $\delta 3.96(3 \mathrm{H} ; \mathrm{s})$ and $3.88(3 \mathrm{H} ; \mathrm{s})$ corresponded to the 


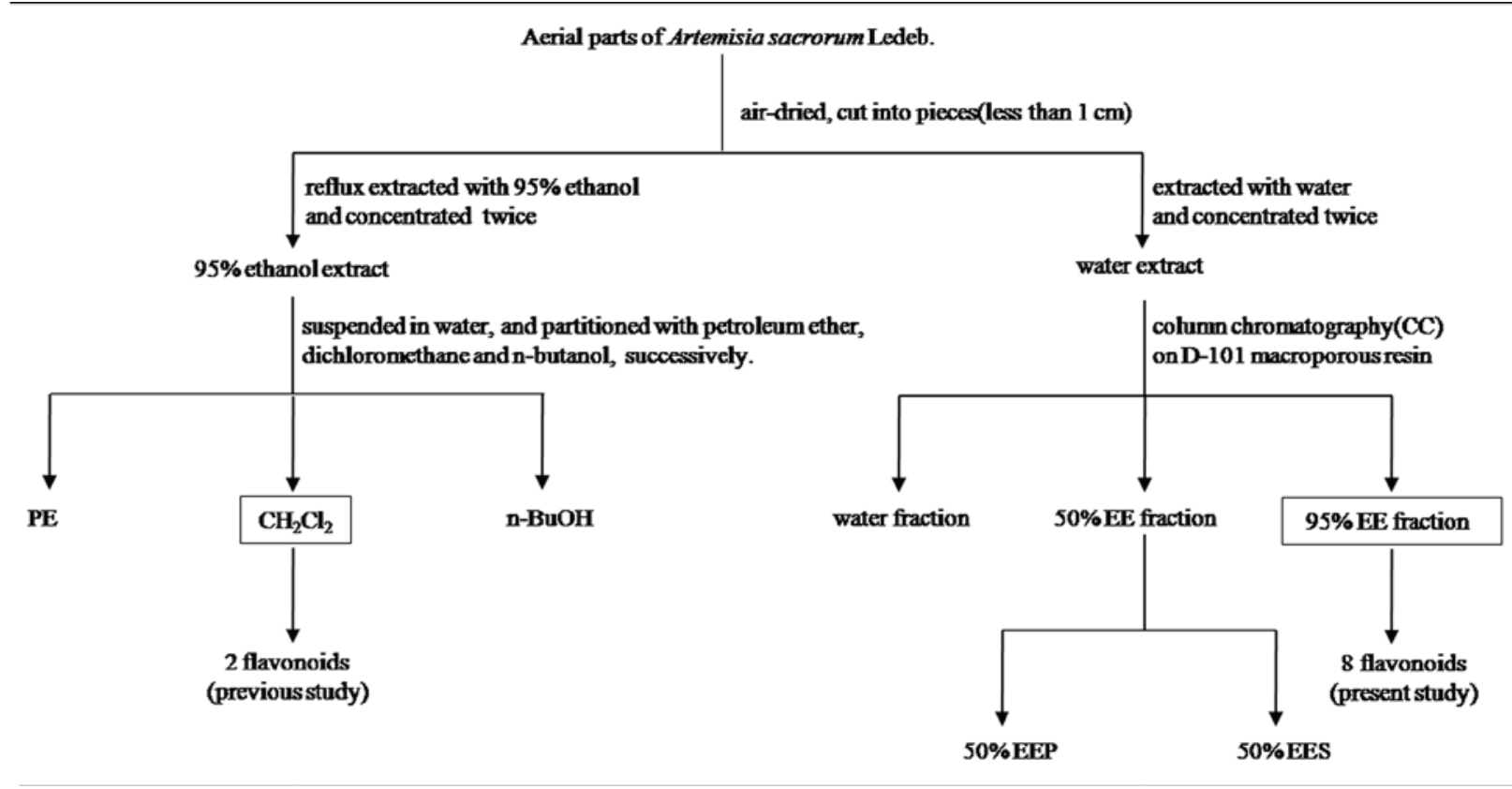

Figure 1. Extraction scheme for the isolation of 10 flavonoids from the 2 most cytotoxic fractions of Artemisia sacrorum Ledeb. By shade-dried we mean that the aerial parts of the herb were air-dried in the shade. EE, ethanol eluate; PE, petroleum ether; EEP, ethanol eluate precipitation; EES, ethanol eluate supernatant.

proton signals of the 2 methoxy groups. The ${ }^{13} \mathrm{C}-\mathrm{NMR}$ spectrum showed 17 carbon signals of which $\delta_{\mathrm{C}} 184.23$ was the carbonyl signal, whereas 56.71 and 60.94 were assigned to 2 methoxy groups. By analyzing these data and comparing them with those in the literature (19), the structure of compound 1 was determined as jaceosidin (Fig. 3).

Compound 2 was obtained as a yellow powder $(\mathrm{MeOH})$. The ${ }^{1} \mathrm{H}-\mathrm{NMR}$ spectrum demonstrated 2 meta-coupled proton signals at $\delta 6.18(1 \mathrm{H} ; \mathrm{d} ; J=2.0 \mathrm{~Hz} ; \mathrm{H}-6)$ and $6.40(1 \mathrm{H} ; \mathrm{d}$; $J=2.0 \mathrm{~Hz} ; \mathrm{H}-8)$ of the A ring. Two groups of meta-coupled proton signals at $\delta 6.90\left(2 \mathrm{H} ; \mathrm{d} ; J=9.0 \mathrm{~Hz} ; \mathrm{H}-3^{\prime} ; \mathrm{H}-5^{\prime}\right)$ and 8.09 (2H; d; $J=9.0 \mathrm{~Hz}$; H-2'; H-6') were assigned to 4 protons in the $\mathrm{B}$ ring. The ${ }^{13} \mathrm{C}-\mathrm{NMR}$ spectrum revealed carbon signals of $\delta_{\mathrm{C}}$ $148.15,137.17,177.44,158.35,99.38,165.77,94.55,162.53$, and 104.56 for the A ring, and 123.81, 130.69, 116.35, 160.57, 116.35, and 130.69 for the B ring. Based on the above spectral data and comparison with a previous study (20), the chemical structure of compound 2 was determined as kaempferol.

Compound 6 was obtained as yellow, needle-like crystals $(\mathrm{MeOH})$. The ${ }^{1} \mathrm{H}-\mathrm{NMR}$ spectrum revealed 2 isolated proton signals at $\delta 6.58(1 \mathrm{H} ; \mathrm{s} ; \mathrm{H}-3)$ and $6.67(1 \mathrm{H} ; \mathrm{s} ; \mathrm{H}-8)$, which were attributed to H-3 (C-ring) and H-8 (A-ring), respectively. Two groups of meta-coupled proton signals at $\delta 6.92(2 \mathrm{H}$; d; $J=8.75 \mathrm{~Hz}$; H-3'; H-5') and $7.84(2 \mathrm{H}$; d; J=8.75 Hz; H-2'; $\mathrm{H}-6$ ') were assigned to 4 protons of the $\mathrm{B}$ ring. The ${ }^{13} \mathrm{C}-\mathrm{NMR}$ spectrum showed $\delta_{\mathrm{C}}$ values of $164.46,102.46,184.31,152.69$, $131.70,157.66,94.17,152.69$, and 104.87 for the A ring, and $122.14,128.45,116.15,161.32,116.15$, and 128.45 for the B ring. These spectroscopic data were characteristic of a flavonoid. Based on the above spectral data and comparison with previous studies $(21,22)$, the chemical structure of compound 6 was determined as hispidulin.

Compound 8 was obtained as a yellow powder (acetone). ${ }^{1} \mathrm{H}-\mathrm{NMR}$ revealed, in the aromatic region, 2 meta-coupled proton signals at $\delta 6.25(1 \mathrm{H}$; d; $J=2.07 \mathrm{~Hz} ; \mathrm{H}-6)$ and $6.46(1 \mathrm{H}$; $\mathrm{d} ; J=2.07 \mathrm{~Hz} ; \mathrm{H}-8)$ for the A ring. ${ }^{1} \mathrm{H}-\mathrm{NMR}$ also demonstrated 2 meta-coupled proton signals at $\delta 7.49(1 \mathrm{H} ; \mathrm{d} ; J=2.07 \mathrm{~Hz}$; H-2'), 7.39 (1H; dd; $\left.J=2.07 ; 8.34 \mathrm{~Hz} ; \mathrm{H}-6{ }^{\prime}\right)$, and 1 isolated proton signal at $\delta 6.98\left(1 \mathrm{H} ; \mathrm{d} ; J=8.34 \mathrm{~Hz} ; \mathrm{H}-5^{\prime}\right)$ for the B ring. These 3 proton signals exhibited the typical three-spin system of the 1',3',4'-trisubstituted B ring. $\delta 5.28(1 \mathrm{H}$; d; $J=1.5 \mathrm{~Hz}$; $\left.\mathrm{H}-1^{\prime \prime}\right)$ was the anomeric proton signal of sugar. The ${ }^{13} \mathrm{C}-\mathrm{NMR}$ spectrum revealed a carbonyl proton signal at $\delta_{\mathrm{C}} 179.18$, which was assigned to C-4, and 17.63-102.57 ppm for a group of 6-carbon sugar signals revealing the presence of an aglycone moiety. Based on the above spectral data and a comparison with previous studies $(23,24)$, the chemical structure of compound 8 was determined as quercitrin.

In addition to the above-mentioned compounds, 5 other compounds were also identified as chrysoeriol (compound 3) (25), quercetin (compound 4) (26), apigenin (compound 5) (27), luteolin (compound 7) $(28,29)$ and scopoletin (compound A) (30). These were identified by interpretation of their spectroscopic data and comparison of the data with the reported values. Among them, compounds 1-8 were flavonoids, and flavonoids 1, 2, 4, 7 and 8 were isolated for the first time from A. sacrorum. The structures of the 8 flavonoids are depicted in Fig. 3 and all ${ }^{13} \mathrm{C}-\mathrm{NMR}$ spectra data were listed in Table I.

A total of 8 flavonoids isolated from the $95 \%$ EE fraction of A. sacrorum were designated as flavonoids 1-8, and 2 flavonoids (genkwanin and acacetin) previously isolated from the $\mathrm{CH}_{2} \mathrm{Cl}_{2}$ fraction were designated as flavonoids 9 and 10 . Although these 10 flavonoids were not novel compounds, their possible biological activities should not be ignored because they have previously been identified. Furthermore, not every novel compound is examined for all its activities (even in vitro experiments before it is considered to be old). Conversely, the majority of novel compounds have only undergone in vitro activity tests. 


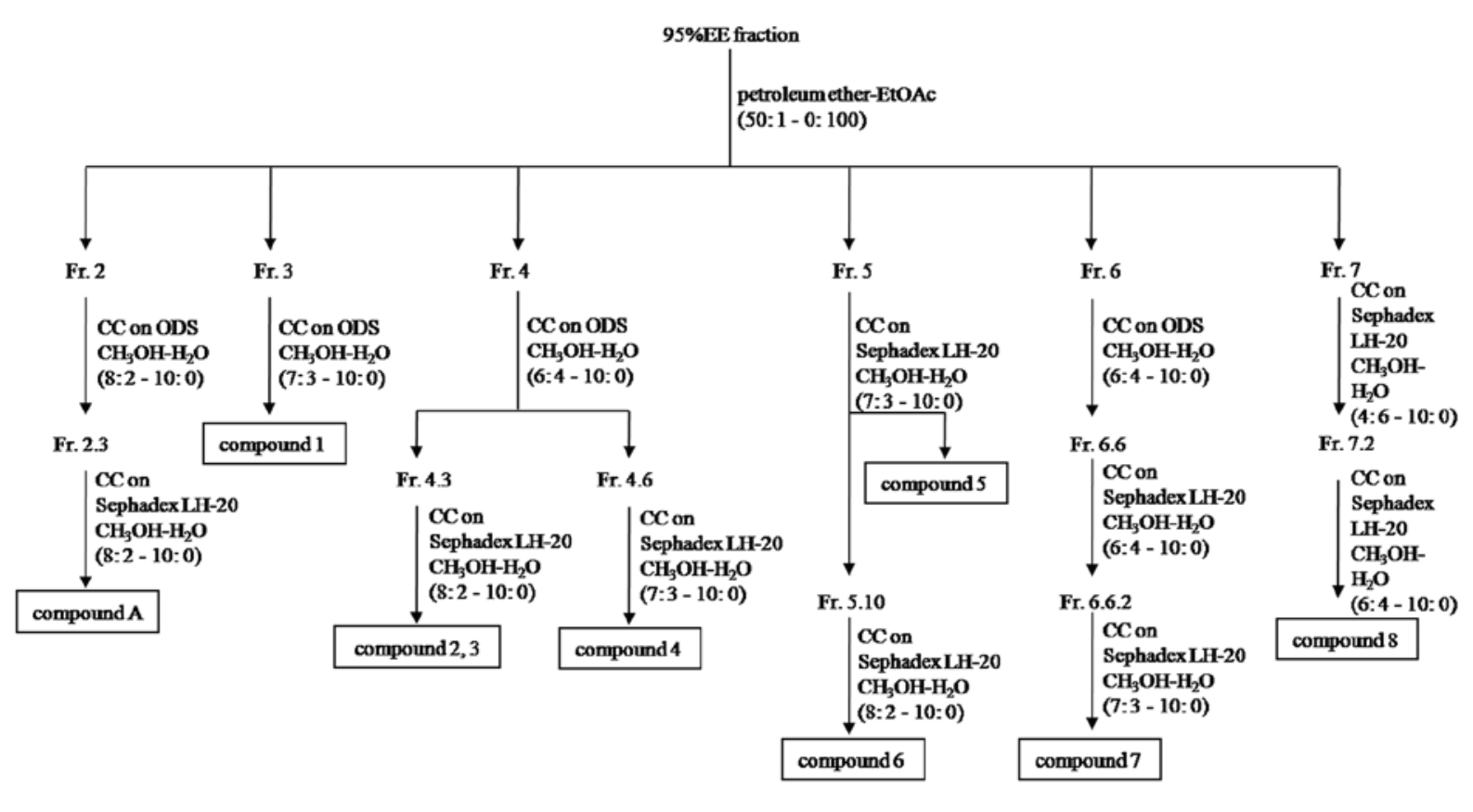

Figure 2. Extraction and separation of 8 flavonoids and 1 coumarin from the 95\% EE fraction. Fr, fraction; EE, ethanol eluate.<smiles>COc1cc(-c2cc(=O)c3c(O)c(O)c(O)cc3o2)ccc1O</smiles><smiles>O=c1c(O)c(-c2ccc(O)cc2)oc2cc(O)cc(O)c12</smiles><smiles>O=c1cc(-c2ccc(O)c(O)c2)oc2cc(O)cc(O)c12</smiles><smiles>O=c1c(O)c(-c2ccc(O)c(O)c2)oc2cc(O)cc(O)c12</smiles><smiles>O=c1cc(-c2ccc(O)cc2)oc2cc(O)cc(O)c12</smiles><smiles>COc1c(O)cc2oc(-c3ccc(O)cc3)cc(=O)c2c1O</smiles><smiles>O=c1cc(-c2ccc(O)c(O)c2)oc2cc(O)cc(O)c12</smiles><smiles></smiles>

Figure 3. Chemical structures of 8 flavonoids from the 95\% EE fraction from Artemisia sacrorum Ledeb. 1-8 represent the compound numbers. EE, ethanol eluate.

In the present study, the cytotoxic activities against the 10 flavonoids on SK-HEP-1, HeLa and HEK293 cell growth were determined using an MTS assay (31). Their $\mathrm{IC}_{50}$ values were presented in Table II, in which apigenin (flavonoid 5) and luteolin (flavonoid 7) exhibited strong cytotoxic activities against human cervical cancer HeLa cells. Conversely, they had 
Table I. ${ }^{13} \mathrm{C}-\mathrm{NMR}$ spectra data of compounds 1-8 ( $\mathrm{\delta}$, ppm; compounds 4 and 8 were detected at $75 \mathrm{MHz}$, others at $125 \mathrm{MHz}$; compounds 1, 2, 3, 4, 6 and 7 dissolved in $\mathrm{CD}_{3} \mathrm{OD}$, compound 5 dissolved in DMSO, and compound 8 dissolved in acetone- $\mathrm{d}_{6}$; $\mathrm{OMe}, \mathrm{OCH} 3)$.

\begin{tabular}{|c|c|c|c|c|c|c|c|c|}
\hline Compound no. & 1 & 2 & 3 & 4 & 5 & 6 & 7 & 8 \\
\hline 2 & 166.24 & 148.15 & 160.89 & 147.99 & 164.17 & 164.46 & 164.73 & 158.15 \\
\hline 3 & 103.80 & 137.17 & 104.15 & 137.24 & 103.04 & 102.46 & 104.62 & 135.63 \\
\hline 4 & 184.23 & 177.44 & 183.79 & 177.34 & 181.77 & 184.31 & 183.66 & 179.18 \\
\hline 5 & 154.70 & 158.35 & 163.13 & 158.23 & 157.48 & 152.69 & 162.33 & 163.06 \\
\hline 6 & 132.97 & 99.38 & 123.75 & 99.22 & 98.90 & 131.70 & 99.78 & 99.35 \\
\hline 7 & 158.90 & 165.77 & 166.09 & 162.52 & 163.88 & 157.66 & 165.61 & 164.77 \\
\hline 8 & 95.38 & 94.55 & 95.31 & 94.39 & 94.16 & 94.17 & 94.75 & 94.35 \\
\hline 9 & 154.70 & 162.53 & 156.19 & 165.58 & 161.22 & 152.69 & 158.25 & 157.63 \\
\hline 10 & 105.78 & 104.56 & 105.39 & 104.52 & 103.77 & 104.87 & 103.89 & 105.75 \\
\hline $1^{\prime}$ & 123.78 & 123.81 & 124.69 & 148.77 & 121.38 & 122.14 & 122.31 & 122.43 \\
\hline $2^{\prime}$ & 110.75 & 130.69 & 110.70 & 115.98 & 128.56 & 128.45 & 114.22 & 115.99 \\
\hline $3^{\prime}$ & 149.52 & 116.35 & 149.58 & 124.14 & 116.05 & 116.15 & 146.78 & 145.68 \\
\hline $4^{\prime}$ & 152.13 & 160.57 & 152.52 & 146.22 & 161.06 & 161.32 & 150.71 & 148.85 \\
\hline $5^{\prime}$ & 116.81 & 116.35 & 116.86 & 116.22 & 116.05 & 116.15 & 116.01 & 116.56 \\
\hline $6^{\prime}$ & 121.76 & 130.69 & 121.77 & 121.67 & 128.56 & 128.45 & 120.46 & 122.73 \\
\hline $\mathrm{OMe}$ & 56.71 & & 56.72 & & & 59.85 & & \\
\hline $\mathrm{OMe}$ & 60.94 & & & & & & & \\
\hline $1^{\prime \prime}$ & & & & & & & & 102.57 \\
\hline $2^{\prime \prime}$ & & & & & & & & 71.26) \\
\hline $3^{\prime \prime}$ & & & & & & & & 71.97) \\
\hline 4" & & & & & & & & 72.86) \\
\hline $5^{\prime \prime}$ & & & & & & & & 71.19 \\
\hline $6^{\prime \prime}$ & & & & & & & & 17.63 \\
\hline
\end{tabular}

The table values represent ${ }^{13} \mathrm{C}-\mathrm{NMR}$ spectra data of compounds $1-8$. OMe represents $\mathrm{OCH}_{3}$. NMR, nuclear magnetic resonance; DMSO, dimethyl sulfoxide.

no cytotoxic activity against normal human embryonic kidney HEK293 cells.

The structures of the 10 flavonoids are similar. However, certain flavonoids revealed different cytotoxic activity against the two human liver cancer SK-HEP-1 and human cervical cancer HeLa cells. Although certain flavonoids have similar chemical structures, there are still compound-specific effects on certain neoplasms that are relevant to adjust specific biochemical processes to treat certain neoplasms differentially $(32,33)$. In the present study, the majority of the 10 flavonoids demonstrated no cytotoxic activity against normal human embryonic kidney cells.

Flavonoids may serve as clinically significant chemotherapeutic agents in the treatment of cancer. Indeed, flavonoids have been demonstrated to reveal cytotoxic activities towards numerous human cancer cells, whilst having little or no effect on normal cells. This has led to interest in the development of potential flavonoid-based chemotherapeutics for anticancer treatment (34-37). Traditional Chinese herbs, which depend predominantly on empirical medication, have been used for thousands of years in the treatment of numerous diseases, often with few adverse effects. Furthermore, many of the active flavonoids in traditional Chinese herbs have been the subject of studies aiming to develop novel anti-cancer drugs by
Table II. Cytotoxities of 10 flavonoids isolated from Artemisia sacrorum $\left(\mathrm{IC}_{50}, \mu \mathrm{M}\right)$.

\begin{tabular}{cccc}
\hline Flavonoids & SK-HEP1 & HeLa & HEK293 \\
\hline 1 & $>50$ & $>50$ & 14.1380 \\
2 & $>50$ & 45.809 & $>50$ \\
3 & 47.19 & $>50$ & $>50$ \\
4 & 45.96 & $>50$ & $>50$ \\
5 & 46.56 & 6.092 & $>50$ \\
6 & 49.93 & $>50$ & $>50$ \\
7 & $>50$ & 16.254 & $>50$ \\
8 & $>50$ & $>50$ & $>50$ \\
9 & $>50$ & 47.834 & $>50$ \\
10 & $>50$ & $>50$ & $>50$ \\
\hline
\end{tabular}

All compounds with $\mathrm{IC}_{50}$ values $>50 \mu \mathrm{M}$ were considered inactive.

demonstrating their activity through in vivo and in vitro experiments (38-40). The diverse flavonoids in these herbal medicines may be promising candidates in the development of novel anti-cancer drugs. 


\section{Acknowledgements}

The present study was supported by the Natural Science Foundation of China (grant no. 81260669). The authors are grateful to Mr. Guang-Hao Zheng and Mr. Zhi-Yong Li for their support during the extraction and fractionation procedures. We also thank Dr. Ming-Shan Zheng for her help in the chemical structure elucidation of several compounds.

\section{References}

1. Li-Weber M: New therapeutic aspects of flavones: The anticancer properties of Scutellaria and its main active constituents Wogonin, Baicalein and Baicalin. Cancer Treat Rev 35: 57-68, 2009.

2. Samarghandian S, Afshari JT and Davoodi S: Chrysin reduces proliferation and induces apoptosis in the human prostate cancer cell line pc-3. Clinics (Sao Paulo) 66: 1073-1079, 2011.

3. Tundis R, Loizzo MR, Menichini F, Bonesi M, Colica C and Menichini F: In vitro cytotoxic activity of extracts and isolated constituents of Salvia leriifolia Benth. against a panel of human cancer cell lines. Chem Biodivers 8: 1152-1162, 2011.

4. Sak K: Cytotoxicity of dietary flavonoids on different human cancer types. Pharmacogn Rev 8: 122-146, 2014.

5. Newman DJ and Cragg GM: Natural products as source of new drugs over the last 25 years. J Nat Prod 70: 461-477, 2007.

6. Dong J: The relationship between traditional chinese medicine and modern medicine. Evid Based Complement Alternat Med 2013: 153148, 2013.

7. Piao MJ, Cui SN and Zhang DY: Korean ethnic Materia Medica in China. Yanji, China: Yanbian People Press. Yan Bian Ren Min Chu Ban She 244-245, 2012.

8. Jia MR and Li XW: Chinese ethnic Materia Medica. Zhong Guo Yi Yao Ke Ji Chu Ban She 69, 2005.

9. Piao GC and Quan YC: Protective effects of extracts of Artemisia sacrorum Ledeb. on acute hepatic injury in mice. Shi Zhen Guo Yi Guo Yao 18: 1646-1647, 2007 (In Chinese).

10. Yuan HD, Jin GZ and Piao GC: Protective effects of the supernatant of ethanol eluate from Artemisia sacrorum Ledeb. against acetaminophen-induced liver injury in mice [corrected]. Biol Pharm Bull 32: 1683-1688, 2009.

11. Yuan HD, Jin GZ and Piao GC: Hepatoprotective effects of an active part from Artemisia sacrorum Ledeb. against acetaminophen-induced toxicity in mice. J Ethnopharmacol 127: 528-533, 2010.

12. YuanHDandPiao GC: An active part of ArtemisiasacrorumLedeb. inhibits adipogenesis via the AMPK signaling pathway in 3T3-L1 adipocytes. Int J Mol Med 27: 531-536, 2011.

13. Yuan HD, Yuan HY, Chung SH, Jin GZ and Piao GC: An active part of Artemisia sacrorum Ledeb. attenuates hepatic lipid accumulation through activating AMP-activated protein kinase in human HepG2 cells. Biosci Biotechnol Biochem 74: 322-328, 2010 .

14. YuanHDandPiaoGC: Anactivepart of ArtemisiasacrorumLedeb. inhibits adipogenesis via the AMPK signaling pathway in 3T3-L1 adipocytes. Int J Mol Med 27: 531-536, 2011.

15. Piao GC, Li YX, Yuan HD and Jin GZ: Cytotoxic fraction from Artemisia sacrorum Ledeb. against three human cancer cell lines and separation and identification of its compounds. Nat Prod Res 26: 1483-1491, 2012.

16. Chien CS, Shen KH, Huang JS, Ko SC and Shih YW: Antimetastatic potential of fisetin involves inactivation of the $\mathrm{PI} 3 \mathrm{~K} / \mathrm{Akt}$ and JNK signaling pathways with downregulation of MMP-2/9 expressions in prostate cancer PC-3 cells. Mol Cell Biochem 333: 169-180, 2010.

17. Chung CS, Jiang Y, Cheng D and Birt DF: Impact of adenomatous polyposis coli (APC) tumor supressor gene in human colon cancer cell lines on cell cycle arrest by apigenin. Mol Carcinog 46: 773-782, 2007.

18. Takagaki N, Sowa Y, Oki T, Nakanishi R, Yogosawa S and Sakai T: Apigenin induces cell cycle arrest and p21/WAF1 expression in a p53-independent pathway. Int J Oncol 26: 185-189, 2005.

19. Wang QH, Wu XL and Wang JH: Study on chemical constituents of Artemisia frigida (II): Chin Tradit Herb Drug 42: 1075-1078, 2011.
20. Yu DQ and Yang JS (eds): Analytical Chemistry Handbook, Vol 7, 2nd edition. Beijing Chemical industry Press 820, Beijing, pp820 1999.

21. Hazekamp A, Verpoorte $\mathrm{R}$ and Panthong $\mathrm{A}$ : Isolation of a bronchodilator flavonoid from the Thai medicinal plant Clerodendrum petasites. J Ethnopharmacol 78: 45-49, 2001.

22. Zhou LD, Yu JG, Guo J and Yang SL: Compounds from roots of Chirita fimbrisepala Hand.-Mazz. Zhongguo Zhong Yao Za Zhi 26: 114-117, 2001 (In Chinese).

23. Wang HP, Cao F and Yang XW: Chemical constituents in aerial parts of Polygonum capitatum. Zhong Cao Yao 44: 24-30, 2013.

24. Lu J and Kong LY: Studies on the Constituents of Hypericum japonicum Thunb. Ex Murray. Zhong Guo Xian Dai Zhong Yao 9: 12-13, 2007.

25. Wei JH, Chen J, Cai SF, Lu RM and Lin SW: Chemical constituents in whole herb of Cardiospermum halicacabum (I). Zhong Cao Yao 42: 1509-1511, 2011.

26. Luo QH, Bu XY, Liu HW, Fan M, Ding AS and Yao XS: Studies on the anti-hypoxia active Constituents of Artemisia scoparia. Zhong Cao Yao Zeng Kan 37: 199-201, 2006.

27. Nan HH, Zhang S and Wu J: Chemical constituents from Clerodendrum inerme. Zhong Cao Yao 36: 492-494, 2005.

28. Wei TM, Yan YN, Guan XL, Liu YF and Wei DH: Analysis of the chemical constituents of the ground part of Sedum sarmentosum. J B Univ TCM 26: 59-61, 2003.

29. Xu ZH, Wu HX, Wei XY, Feng SX and Hu TM: Flavonoids from Lespedeza davurica. Acta Bot Boreal-Occident Sin 30: 1485-1489, 2010.

30. Xie T, Liang JY, Liu J, Wang M, Wei XL and Yang CH: Chemical Study on Artemisia scoparia. J China Pharm Univ 35: 401- 403, 2004.

31. Kometani T, Yoshino I, Miura N, Okazaki H, Ohba T, Takenaka T, Shoji F, Yano T and Maehara Y: Benzo[a]pyrene promotes proliferation of human lung cancer cells by accelerating the epidermal growth factor receptor signaling pathway. Cancer Lett 278: 27-33, 2009.

32. Bonham M, Posakony J, Coleman I, Montgomery B, Simon J and Nelson PS: Characterization of chemical constituents in Scutellaria baicalensis with antiandrogenic and growth-inhibitory activities toward prostate carcinoma. Clin Cancer Res 11: 3905-3914, 2005.

33. Zheng Q, Hirose Y, Yoshimi N, Murakami A, Koshimizu K, Ohigashi H, Sakata K, Matsumoto Y, Sayama Y and Mori H: Further investigation of the modifying effect of various chemopreventive agents on apoptosis and cell proliferation in human colon cancer cells. J Cancer Res Clin Oncol 128: 539-546, 2002.

34. Xu XF, Cai BL, Guan SM, Li Y, Wu JZ, Wang Y and Liu B: Baicalin induces human mucoepidermoid carcinoma Mc3 cells apoptosis in vitro and in vivo. Invest New Drugs 29: 637-645, 2011.

35. Chen WY, Hsieh YA, Tsai CI, Kang YF, Chang FR, Wu YC and $\mathrm{Wu} \mathrm{CC}$ : Protoapigenone, a natural derivative of apigenin, induces mitogen-activated protein kinase-dependent apoptosis in human breast cancer cells associated with induction of oxidative stress and inhibition of glutathione S-transferase TT. Invest New Drugs 29: 1347-1359, 2011.

36. Plochmann K, Korte G, Koutsilieri E, Richling E, Riederer P, Rethwilm A, Schreier P and Scheller C: Structure-activity relationships of flavonoid-induced cytotoxicity on human leukemia cells. Arch Biochem Biophys 460: 1-9, 2007.

37. Ben Sghaier M, Skandrani I, Nasr N, Franca MG, Chekir-Ghedira L and Ghedira K: Flavonoids and sesquiterpenes from Tecurium ramosissimum promote antiproliferation of human cancer cells and enhance antioxidant activity: A structure-activity relationship study. Environ Toxicol Pharmacol 32: 336-348, 2011.

38. Luo Y, Sun G, Dong X, Wang M, Qin M, Yu Y and Sun X: Isorhamnetin attenuates atherosclerosis by inhibiting macrophage apoptosis via PI3K/AKT activation and HO-1 induction. PLoS One 10: e0120259, 2015.

39. Chen X, Zhang B, Yuan X, Yang F, Liu J, Zhao H, Liu L, Wang Y, Wang Z and Zheng Q: Isoliquiritigenin-induced differentiation in mouse melanoma B16F0 cell line. Oxid Med Cell Longev: Dec 10, 2012 (Epub ahead of print) doi: 10.1155/2012/534934.

40. Wang B: General research on effects of flavonoids ingredients on Chinese herbs on anti-cancer. Zhe Jiang Zhong Yi Yao Da Xue Xue 36: 838-840, 2012 (In Chinese). 